University of Nebraska - Lincoln

DigitalCommons@University of Nebraska - Lincoln

Faculty Publications: Department of

Entomology

Entomology, Department of

2006

\title{
Diabrotica virgifera virgifera (Coleoptera: Chrysomelidae) Larval Feeding Behavior on Transgenic Maize (MON 863) and Its Isoline
}

Pete L. Clark

University of Nebraska-Lincoln

Ty T. Vaughn

Monsanto Company, St. Louis, MO

Lance J. Meinke

University of Nebraska-Lincoln, Imeinke1@unl.edu

Jaime Molina-Ochoa

Universidad de Colima, Mexico, jmolina18@hotmail.com

John E. Foster

University of Nebraska-Lincoln, john.foster@unl.edu

Follow this and additional works at: https://digitalcommons.unl.edu/entomologyfacpub

Part of the Entomology Commons

Clark, Pete L.; Vaughn, Ty T.; Meinke, Lance J.; Molina-Ochoa, Jaime; and Foster, John E., "Diabrotica virgifera virgifera (Coleoptera: Chrysomelidae) Larval Feeding Behavior on Transgenic Maize (MON 863) and Its Isoline" (2006). Faculty Publications: Department of Entomology. 262.

https://digitalcommons.unl.edu/entomologyfacpub/262

This Article is brought to you for free and open access by the Entomology, Department of at DigitalCommons@University of Nebraska - Lincoln. It has been accepted for inclusion in Faculty Publications: Department of Entomology by an authorized administrator of DigitalCommons@University of Nebraska - Lincoln. 


\title{
Diabrotica virgifera virgifera (Coleoptera: Chrysomelidae) Larval Feeding Behavior on Transgenic Maize (MON 863) and Its Isoline
}

\author{
PETE L. CLARK, ${ }^{1,2}$, TY T. VAUGHN, ${ }^{3}$ LANCE J. MEINKE, ${ }^{2}$ JAIME MOLINA-OCHOA, ${ }^{4}$ \\ AND JOHN E. FOSTER ${ }^{2}$
}

\begin{abstract}
J. Econ. Entomol. 99(3): 722-727 (2006)
ABSTRACT Diabrotica species (Coleoptera: Chrysomelidae) larval behavior studies have posed a challenge to researchers because of the subterranean life cycle of this pest. To fully understand how the western corn rootworm, Diabrotica virgifera virgifera LeConte, injures the maize, Zea mays L., root system, its behavior must be studied. For example, larvae that can detect an area of the root that has a lower amount of toxin, whether from an insecticide or a transgenic maize plant, have an increased chance of survival. This study assessed $D$. v. virgifera larval feeding behavior on rootworm-susceptible maize and maize containing a biotechnology-derived trait (MON 863) with resistance to D. v. virgifera first instar feeding. Maize plants were grown in a medium that allowed for direct observation and measurements during feeding of larval stadia. Neonates were placed on maize seedlings, and data were taken at 3, 6, 9, and $12 \mathrm{~d}$ postinfestation on resistant and susceptible maize. On rootworm-susceptible maize, neonate larvae aggregated at the root tips and began actively feeding, and then they moved to older root tissue. Conversely, some larvae that ingested Cry 3Bbl from the resistant maize exhibited no movement. Other larvae on the resistant maize moved continuously, sampling root hairs or root tissue but not actively feeding. The continuously moving larvae had visibly empty guts, suggesting possible nonpreference for the resistant root. This study contributes to our understanding of $D . v$. virgifera larval behavior and provides insight into questions surrounding the potential evolution of behavioral and biochemical resistance to Cry3Bbl.
\end{abstract}

KEY WORDS western corn rootworm, transgenic maize, biotechnology derived trait

Species of Diabrotica that attack maize, Zea mays L., are known as the corn rootworm complex, and western corn rootworm, Diabrotica virgifera virgifera LeConte, in particular, is one of the most important pests of maize in the Corn Belt. Larvae of $D$. v. virgifera injure maize plants by feeding on root tissue. Producers historically have applied insecticides or used crop rotation to control the corn rootworm complex. However, pest Diabrotica species have repeatedly exhibited the ability to adapt to management practices, making it more difficult to minimize the risk of economic loss. Intensive management has selected for significant levels of resistance to methyl parathion and carbaryl within adult (Meinke et al. 1998) and larval (Wright et al. 2000) D. v. virgifera populations in certain areas of Nebraska. In the eastern Corn Belt, long-term use of corn-Glycine $\max (\mathrm{L}$.) Merr. (soybean) rotation has apparently selected for a variant $D$. v. virgifera strain whose females oviposit in other crops

\footnotetext{
${ }^{1}$ Monsanto Company, 800 North Lindbergh Blvd., St. Louis, MO 63167.

2 Department of Entomology, University of Nebraska-Lincoln, Lincoln, NE 68583-0816.

${ }^{3}$ Monsanto Company, 700 Chesterfield Pkwy. West, St. Louis, MO 63198.

${ }^{4}$ Facultad de Ciencas Biológicas y Agropecuarias, Universidad de Colima, Colima 28100, Mexico.
}

as well as corn, thus allowing $D$. v. virgifera populations to circumvent crop rotation as a management tactic (Levine et al. 2002). The northern corn rootworm, Diabrotica barberi Smith \& Lawrence, can produce diapausing eggs that do not hatch for $2 \mathrm{yr}$ (extended diapause); this trait also eliminates the cultural advantage of crop rotation from soybean to maize (Chiang 1965, Krysan et al. 1984).

As new rootworm management technologies are developed, research on larval behavior has become more important because of the need to understand larval host finding and feeding in greater detail. Behavioral adaptation is a particularly important consideration when developing transgenic maize hybrids that have resistance to Diabrotica spp. Many studies over the past $20 \mathrm{yr}$ have sought to answer the biological question of how D. v. virgifera finds its host plant (eg., Branson 1982). Olfactory response to $\mathrm{CO}_{2}$ has been studied in relation to the host finding capacity of D. v. virgifera larvae (Strnad et al. 1986; Bernklau and Bjostad 1998a,b). $\mathrm{CO}_{2}$ seems to be the key attractant used by D. v. virgifera larvae to find potential host plants (Strnad and Bergman 1987b, Bernklau and Bjostad 1998b).

Movement of D. v. virgifera through the soil also is important for host location. The distance neonate larvae are capable of moving through the soil in search 
of a host root is dependent on soil type, moisture, porosity, and bulk density of the soil (Krysan 1999). Strnad and Bergman (1987a) found D. v. virgifera first instars in the seminal roots as well as roots in the first five whorls; significantly more first and second instars were encountered at the root tip than the root base.

The use of transgenic plants to control pest populations is a new approach to host plant resistance. Monsanto Company (St. Louis, MO) has developed a transgenic maize that expresses the $\mathrm{Cry} 3 \mathrm{Bb} 1$ protein (MON 863) conferring resistance to larval feeding by Diabrotica virgifera zeae Krysan \& Smith, D. v. virgifera, and D. barberi (Vaughn et al. 2005). This maize has been approved for commercial use and is marketed under the name YieldGard Rootworm. Our objective of this study was to assess $D$. v. virgifera larval feeding behavior on susceptible (nontransgenic) plants and to compare behavioral differences in larval feeding on transgenic rootworm-resistant maize and a nontransgenic isoline.

\section{Materials and Methods}

Seedling Culture and Infestation. A transparent growth medium was used in place of soil to allow direct observations of $D$. $v$. virgifera larvae on maize seedlings. The medium was made in 3-liter batches as described by Davis (1998), with modifications (Clark 2002). The ingredients were mixed and heated in a microwave oven for $\approx 20$ min or until the mixture reached a full boil. The medium was then poured into sterile 95-ml test tubes to within $2 \mathrm{~cm}$ of the top of the test tube. Foil caps were placed on the test tubes after the medium was poured.

Seeds of rootworm-resistant transgenic maize (MON 863) and its nontransgenic isoline were provided by Monsanto Company for this study. Using the procedures from Clark (2002), the seeds were rinsed once with a $0.005 \%$ sodium hypochlorite solution, rinsed nine times with double-distilled water, surfacesterilized under a UV light for $15 \mathrm{~min}$, and imbibed for $12 \mathrm{~h}$ in double distilled water at room temperature. The seeds were germinated under a paper towel saturated with a Captan solution $(0.5 \mathrm{~g} /$ liter $)$. The seeds germinated within $24-48 \mathrm{~h}$ and were grown until the radicle was $\approx 2 \mathrm{~cm}$ in length.

Seedlings were transplanted into test tubes with the medium under sterile conditions in a laminar flow hood. A slit was made into the top of the media and the seedlings were inserted into the opening with only the shoot above the surface of the media. Black construction paper was placed around each test tube to discourage algal growth and to simulate a dark environment for the larvae. The experiment took place in a $24^{\circ} \mathrm{C}$ environmental chamber (Percival Scientific, Perry, IA) set for a photoperiod of 14:10 (L:D) h.

Nondiapausing D. v. virgifera eggs were supplied by Crop Characteristics (Farmington, MN). Larvae were hatched at $24^{\circ} \mathrm{C}$ on a continuous basis. A fine-tipped watercolor brush (size $\mathrm{O}$ ) was used to transfer 20 neonate larvae from the petri dish to each maize seedling $8 \mathrm{~d}$ after transplantation.
Experimental Design. The experiment had three treatments (randomized in the environmental chamber at each replication) in six replications. Treatments were 1) infested transgenic maize, 2) infested isoline, and 3) uninfested isoline. These treatments are referred to as resistant, susceptible, and control treatments, respectively. Data were taken at 3, 6, 9, and $12 \mathrm{~d}$ postinfestation (labeled as day 3, 6, 9, and 12).

Five test tubes with plants were removed from the environmental chamber and taken into the laboratory for analysis on each date. The plant and the medium were carefully removed from the test tube, and the number of $D$. v. virgifera larvae feeding was counted. Feeding location and behavioral observations were evaluated by microscopy before removal of plants and media from each test tube. Each larva was removed from the medium by using a stainless steel spatula and a fine-tipped watercolor brush ( size $\mathrm{O}$ ). The head capsule width was then recorded before placement in a foil weigh boat. The number of larvae recovered was recorded, and wet larval weight was measured using an analytical balance (Mettler-Toledo, Columbus, $\mathrm{OH})$. Head capsule width was used to determine larval stadium (Ball 1957, George and Hintz 1966). Larval head capsule width was measured using an ocular micrometer. Larval weight and head capsule size validated the test system for larval growth, survivability, and experimental reproducibility. Wet root weights were taken after the larval data were collected. Roots were clipped from the stem on each day, washed gently, blotted with a paper towel, and weighed.

Data were analyzed using SAS statistical analysis (SAS Institute 1999-2001). PROC MIXED (least squares means, type 3 tests of fixed effects) was used to analyze larval weight gain over time on the susceptible treatment as an indicator of larval growth and development, root weights on each day, number of larvae extracted each day, number of larvae observed feeding each day, and comparison of larval weights between the resistant and susceptible treatments on day 3. PROC FREQ (Pearson's chi-square) was used to analyze feeding location (root tip or elongated older root tissue) of larvae on the susceptible treatment and to compare the number of larvae extracted on day 3 between the resistant and susceptible treatments.

\section{Results}

Larval Feeding Behavior on Susceptible Plants. D. v. virgifera first instars were observed in feeding aggregations on developing root tissue at the tip where cell formation occurs (Fig. 1). Larvae started feeding at the root tip (Figs. 1 and 2), continued to feed, and moved inside the root. At day 3, all of the actively feeding first instars were feeding at the root tip or were already inside the root. Second and third instars were observed feeding on the inside and outside of the root on days 6,9 , and 12 on the susceptible treatment. Root injury was isolated primarily in and around sites of root cell differentiation (Fig. 1) on day 3. On days 6 and 9, areas of generalized feeding throughout the root sys- 


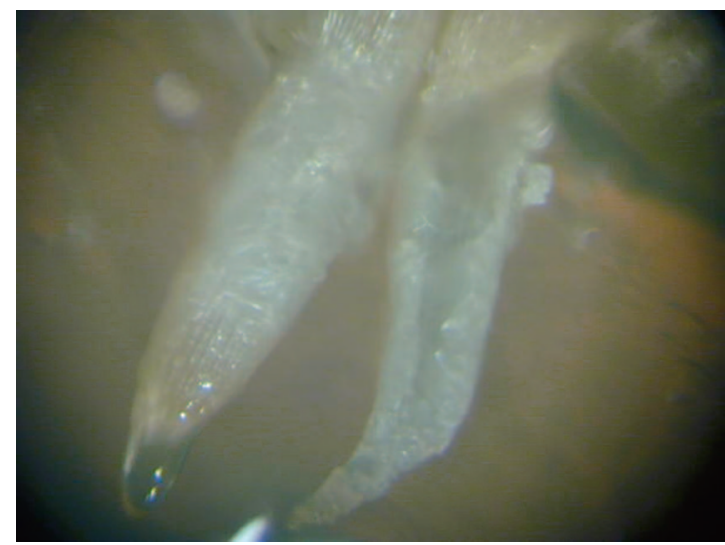

Fig. 1. Isoline maize root. Root on left represents a healthy root with the clear part of the tip as a major source of $\mathrm{CO}_{2}$ and cell differentiation. Root on right represents severe larval injury from a first instar D. v. virgifera (photo by P.L.C.).

tem were apparent on the susceptible treatment, and by day 12 , severe feeding injury was visible on all susceptible roots. Conversely, feeding damage on the roots of the resistant treatment was minimal, which can be correlated to larval mortality ( 257 dead of 600 infested on day 3; 593 dead of 600 infested on day 6; and 600 dead of 600 infested on days 9 and 12). Analysis of day by feeding location confirmed that the feeding location significantly changed over time as more larvae moved to feed on the elongated portion of the root (Table 1 ).

Differences of mean larval weights among days were highly significant in the susceptible treatment (Table 2) $(F=8368.60 ; \mathrm{df}=3,1,141 ; P<0.0001)$. The head capsule widths (measurements at each larval stadium not statistically analyzed) of live larvae indicated molt occurred from first to second instar $6 \mathrm{~d}$ postinfestation and from second to third instar by $12 \mathrm{~d}$ postinfestation, which was complimentary to the increased larval weights (Table 2).

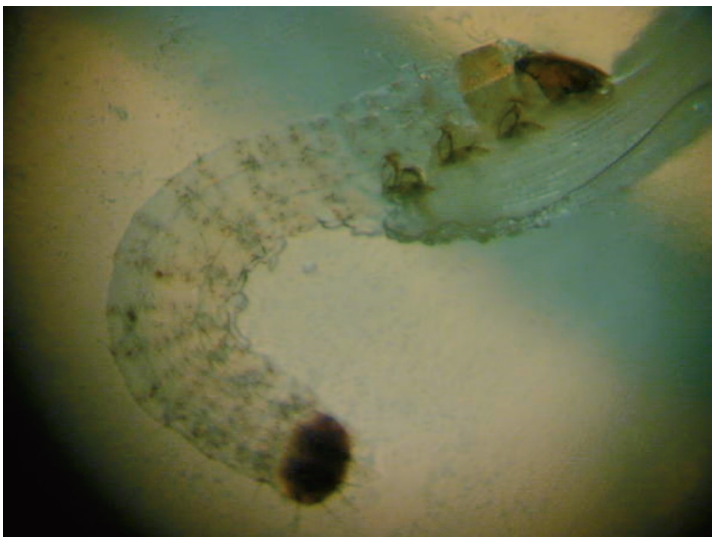

Fig. 2. Neonate D. v. virgifera beginning to feed on an isoline root tip; the gut is visibly empty (photo by P.L.C.).
Table 1. Analysis of larvae feeding at either the root tip or the elongated portion of the root (area other than the root tip) over time on the susceptible treatment

\begin{tabular}{rccc}
\hline \hline Time (d) & $\begin{array}{c}\text { Total } \\
\text { observed }_{\text {feeding }}{ }^{\text {f }}\end{array}$ & $\begin{array}{c}\text { \% feeding } \\
\text { at root tip }\end{array}$ & $\begin{array}{c}\text { \% feeding at } \\
\text { elongated root }\end{array}$ \\
\hline 3 & 92 & 95 & 5 \\
6 & 101 & 60 & 40 \\
9 & 101 & 17 & 83 \\
12 & 99 & 17 & 83 \\
\hline
\end{tabular}

An overall analysis of feeding location showed that most larvae moved from feeding at the root tip to elongated roots by the end of each replication $\left(\chi^{2}=163.3250, \mathrm{df}=3, P<0.0001\right)$.

${ }^{a}$ Represents larvae observed feeding at the time of extraction over $4 \mathrm{~d}$ and six replications on the susceptible treatment.

Larval Feeding Behavior Comparison in Resistant and Susceptible Plants. Larval recovery was measured as the number of live larvae extracted from the medium each date. The resistant treatment had a larval recovery of $8.1 \pm 1.5$ (mean $\pm \mathrm{SE}$ ) larvae per plant compared with the susceptible treatment with a larval recovery of $8.9 \pm 1.5$ larvae per 20 infested per plant per replication on day 3 . The mean number of live larvae recovered from the resistant and susceptible treatments was not significantly different than expected (Pearson's chi-square test: $\chi^{2}=1.9649$, $\mathrm{df}=1$, $P=0.1610$ ) on day 3 . Although the difference in larval recovery on day 3 was not significant between the resistant and susceptible treatments, comparison of feeding behavior on the resistant and susceptible plants provided insight into differences between treatments. Larval behavior at the point of infestation initially was similar between the two treatments. Larvae in both treatments immediately moved into the root zone and oriented toward potential feeding sites. Visual observations of larvae feeding per 20 infested indicated significantly less larvae were feeding on the resistant roots $(0.13 \pm 0.17)$ compared with larvae observed feeding on the susceptible roots (3.07 \pm 0.17 ) on day 3 before extraction from the media $(F=$ 141.47; df $=1,5 ; P<0.0001)$. Mean weights of live larvae in the resistant $(0.000072 \pm 0.0000025 \mathrm{~g}$ per larva) and susceptible $(0.00036 \pm 0.0000025 \mathrm{~g}$ per

Table 2. Mean larval weights and head capsule width from the susceptible treatment as an indicator of larval growth characteristics

\begin{tabular}{cccc}
\hline Time (d) & $\begin{array}{c}\text { Head capsule } \\
\text { width }(\mathrm{mm})^{a}\end{array}$ & Susceptible $(\mathrm{g})^{b}$ & $\begin{array}{c}\text { Total } \\
\text { recovered } \\
\text { of 600 infested } \\
(\% \text { recovered })^{c}\end{array}$ \\
\hline 3 & 0.2 & $0.0004 \pm 0.000016$ & $267(45)$ \\
6 & 0.3 & $0.0011 \pm 0.000015$ & $278(46)$ \\
9 & 0.3 & $0.0022 \pm 0.000015$ & $300(50)$ \\
12 & 0.5 & $0.0039 \pm 0.000015$ & $305(51)$ \\
\hline
\end{tabular}

${ }^{a}$ Measurement done using an ocular micrometer at the time of extraction.

${ }^{b}$ Larval weights (mean $\pm \mathrm{SE}$ ) are significantly different among all days $(F=24.82$; $\mathrm{df}=6,45 ; P<0.0001$; PROC MIXED, least squares means)

${ }^{c}$ Represents 100 larvae per replication over six replications. 
Table 3. Mean $\pm \mathrm{SE}$ root weight of resistant, susceptible, and control treatments

\begin{tabular}{cccc}
\hline \hline Time $(\mathrm{d})$ & Resistant $(\mathrm{g})$ & Susceptible $(\mathrm{g})$ & Control $(\mathrm{g})$ \\
\hline 3 & $1.0618 \pm 0.0495$ & $0.6991 \pm 0.0495$ & $1.0385 \pm 0.0495$ \\
6 & $1.3871 \pm 0.0495$ & $0.8681 \pm 0.0495$ & $1.4129 \pm 0.0495$ \\
9 & $1.7880 \pm 0.0495$ & $1.0718 \pm 0.0495$ & $1.8016 \pm 0.0495$ \\
12 & $2.4379 \pm 0.0495$ & $1.3415 \pm 0.0495$ & $2.5168 \pm 0.0495$ \\
\hline
\end{tabular}

Mean weight of the susceptible treatment on days $3,6,9$, and 12 was significantly lower on each day $(F=24.82$; $\mathrm{df}=6,45 ; P<0.0001$ PROC MIXED, least square means) than the mean weights of resistant or control treatments. Mean weights of resistant and control treatments were not significantly different on any day $(P=0.6812$ for day $3, P=0.6484$ for day $6, P=0.8108$ for day $9, P=0.1670$ for day 12 ; PROC MIXED, least squares means).

larva) treatments were significantly different on day 3 $(F=44245.4 ; \mathrm{df}=1,503 ; P<0.0001)$. Results suggest that although still alive, the larvae on the resistant treatment were consuming significantly less tissue than larvae on the susceptible treatment.

Larvae on the roots of the susceptible treatment were actively feeding in one concentrated area, causing severe root injury. Larvae in the resistant treatment exhibited two types of behavior. The first type of behavior was illustrated by larvae with little body movement and visibly reduced abdominal segments (giving them a flattened appearance). The midgut of these lethargic larvae contained visible root tissue, indicating ingestion. Larvae exhibiting the second observed behavior moved actively up and down the root system and were observed to sample maize root hairs with their mandibles or take small bites of the root tissue, never concentrating on one feeding location. These larvae had visibly empty midguts and died, presumably from starvation.

Differences in root injury were observed between the transgenic and susceptible treatments. A few small scars were seen on the resistant roots where $D . v$. virgifera had taken a bite and then stopped feeding, suggesting nonpreference. By comparison many of the susceptible plants were so damaged that they were bound in the medium by a single root severed completely. The roots in the resistant and control treatments were not injured and had removed much of the moisture from the medium. Conversely, in the susceptible treatment where moisture was present in the media, plants exhibited drought-like symptoms, presumably because of disruption of water and or nutrient uptake. Mean root weights of susceptible plants were significantly lower than root weights of resistant plants $(F=24.82 ; \mathrm{df}=6,45 ; P<0.0001)$ (Table 3$)$. Mean root weights of the resistant and control treatments were not significantly different from each other $(F=24.82$; df $=6,45 ; P=0.4350)$ (Table 3$)$.

\section{Discussion}

Larval Feeding Behavior on Susceptible Plants. D. v. virgifera larvae have been documented to move in maize fields from highly damaged (infested) plants to nearby plants with undamaged roots (Hibbard et al. 2003). The root cap is continually sloughed off as developing cells at the root tip are being formed. The formation of new root cells releases $\mathrm{CO}_{2}$ that is used by the $D$. v. virgifera as a key attractant to locate a potential host (Bernklau and Bjostad 1998b). In this study, neonate larvae placed on the plant at the medium surface quickly moved to feed on actively growing root tissue. First instars aggregated on developing root tissue (Table 3). As the larvae grew, they fed on the elongated portions of the maize root and not at the maize root tip. It was not uncommon throughout this study to find first instars feeding at the root tip or to observe heavy damage at the tip. As the larvae molted to second instar, feeding damage was distributed between newly developing root tissue and older portions of the lateral roots. By the end of each replication, many larvae fed on the older larger portions of the root either on the outside or the inside (although not as prevalent inside the root as exhibited by first instars), possibly because of a larger concentrated area of root tissue. By the end of each replication (day 12), the injury to the maize roots was extensive. Many roots were severed, whereas others were almost completely consumed, leaving only a portion of the dermal tissue intact. The visible root injury and measured decrease in root weights is indicative of larval feeding, as further illustrated by the increasing larval weights and head capsule widths.

Larval Feeding Behavior Comparison in Resistant and Susceptible Plants. The concentrated larval feeding that caused severe root injury is what we expected to observe on the susceptible treatment. The differences in larval behavior on the resistant treatment were somewhat unexpected. We expected to observe larvae that would feed and become lethargic, but they were not expecting the active movement and root hair sampling. We concluded from these observations that there were two groups of larvae: larvae that had fed and were dying, and larvae that presumably had not ingested enough Cry3Bbl protein from the transgenic treatment and were searching for a feeding location. The observed differences in larval movement between the two treatments and $99 \%$ mortality by day 6 in the resistant treatment suggest an antibiotic effect of the resistant maize to first instars, with a possible antixenosis (nonpreference) effect on the nonfeeding larvae.

Lower larval weight of live larvae in the resistant treatment is consistent with the visibly empty midgut of some larvae in the resistant treatment. D. v. virgifera larvae can survive from 3 to $8 \mathrm{~d}$ without eating, based on studies conducted by Branson (1989) and OloumiSadeghi and Levine (1989). The rate of survival is greatly influenced by temperature. Higher temperatures reduce longevity of food-deprived D. v. virgifera neonates. The maximum reported time of starvation that the larvae could survive was $8 \mathrm{~d}$ at $21^{\circ} \mathrm{C}$ and $6 \mathrm{~d}$ at $27^{\circ} \mathrm{C}$ with high mortality (Oloumi-Sadeghi and Levine 1989). However, the highest survival rates under starvation occurred during the first $3 \mathrm{~d}$ at any temperature. Similar results were obtained in this experiment as the highest rate of survival occurred at $3 \mathrm{~d}$ or less at $24^{\circ} \mathrm{C}$. Quiescent or antixenotic behavior of lar- 
vae on the resistant treatment is consistent with the significantly lower larval weights on day 3 .

The significant differences in root weights between the susceptible and resistant treatments verify that larvae in the susceptible treatment were feeding, suggesting this model system is appropriate to study the biology and behavior of Diabrotica spp. larvae. Larval developmental time and head capsule width were within the growth and development parameters (George and Hintz 1966) observed in other test systems, including the field.

This work provides a basis for understanding the interactions that occur at the plant root-insect interface and may help identify the mechanism leading to larval survival on transgenic root tissues. It has been reported that some level of survivorship occurs on YieldGard Rootworm as observed through adult emergence data (Anonymous 2003). How these larvae are able to accomplish this is not entirely clear, but the data presented here strongly suggest that feeding behavior is involved. For example, D. v. virgifera larvae may be able to detect subtle differences in Cry3Bb1 expression in the root system, which would facilitate survival to the next instar (based on observed survival to second instar on day 6). Although this research contributes to our basic understanding of D. v. virgifera larval feeding behavior, which until now has been unobservable on maize roots, it also raises questions about the potential for evolution of behavioral resistance to Cry $3 \mathrm{Bb} 1$ protein and the current refuge requirements in place for $D$. v. virgifera resistance management. If $D$. $v$. virgifera larvae can detect subtle differences in Cry 3Bbl expression and develop to adults on low expressing root tissues, then the plant may essentially contain a built-in refuge that could slow the potential evolution of biochemical resistance to the Cry $3 \mathrm{Bbl}$ protein.

\section{Acknowledgments}

This research was funded in part by the University of Nebraska Project NEB-17-064 and Monsanto Company. This article is a contribution of the University of Nebraska Agricultural Research Division, Lincoln, NE, Journal Series No. 14558.

\section{References Cited}

Anonymous. 2003 Biopesticides Registration Action Document: Event MON 863 Bacillus thuringiensis. Cry3Bb1 Corn. Benefits Assessment, pp. IIE1-IIE34. U.S. Environmental Protection Agency. (http://www.epa. gov/pesticides/biopesticides/ingredients/tech docs/brad 006484.htm).

Ball, H. J. 1957. On the biology and egg-laying habits of the western corn rootworm. J. Econ. Entomol. 50: 126128 .

Bernklau, E. J., and L. B. Bjostad. 1998a. Behavioral responses of first-instar western corn rootworm (Coleoptera: Chrysomelidae) to carbon dioxide in a glass bead bioassay. J. Econ. Entomol. 91: 444-456.
Bernklau, E. J., and L. B. Bjostad. 1998b. Reinvestigation of host location by western corn rootworm larvae (Coleoptera: Chrysomelidae): $\mathrm{CO}_{2}$ is the only volatile attractant. J. Econ. Entomol. 91: 1331-1340.

Branson, T. F. 1982. Olfactory responses of larvae of Diabrotica virgifera virgifera to plant roots. Entomol. Exp. Appl. 31: 303-307.

Branson, T. F. 1989. Survival of starved neonate larvae of Diabrotica virgifera virgifera LeConte (Coleoptera: Chrysomelidae). J. Kans. Entomol. Soc. 62: 521-523.

Chiang, H. C. 1965. Survival of northern corn rootworm eggs through one or two winters. J. Econ. Entomol. 58: $470-472$.

Clark, P. L. 2002. Diabrotica virgifera virgifera LeConte larval feeding behavior. M.S. thesis, University of Nebraska, Lincoln, NE.

Davis, C. S. 1998. A novel bioassay to evaluate maize for Diabrotica virgifera virgifera resistance and characterization of maize root compounds. M.S. thesis, University of Nebraska, Lincoln, NE.

George, B. W., and A. M. Hintz. 1966. Immature stages of the western corn rootworm. J. Econ. Entomol. 59: 11391142 .

Hibbard, B. E., D. P. Duran, M. R. Ellersieck, and M. M. Ellsbury. 2003. Post-establishment movement of western corn rootworm larvae (Coleoptera: Chrysomelidae) in central Missouri corn. J. Econ. Entomol. 96: $599-608$.

Krysan, J. L. 1999. Selected topics in the biology of $D i$ abrotica, pp. 479-513. In M. L. Cox [ed.], Advances in Chrysomelidae biology. Backhuys, Leiden, The Netherlands.

Krysan, J. L., J. J. Jackson, and A. C. Lew. 1984. Field termination of egg diapause in Diabrotica with new evidence of extended diapause in D. barberi (Coleoptera: Chrysomelidae). Environ. Entomol. 13: 1237-1240.

Levine, E., J. L. Spencer, S. A. Isard, D. W. Onstad, and M. E. Gray. 2002. Adaptation of the western corn rootworm to crop rotation: evolution of a new strain in response to a management practice. Am. Entomol. 48: 94107.

Meinke, L. J., B. D. Siegfried, R. J. Wright, and L. D. Chandler. 1998. Adult susceptibility of Nebraska western corn rootworm (Coleoptera: Chrysomelidae) populations to selected insecticides. J. Econ. Entomol. 91: $594-600$.

Oloumi-Sadeghi, H., and E. L. Levine. 1989. Effect of starvation and time of egg hatch on larval survival of the western corn rootworm, Diabrotica virgifera virgifera (Coleoptera: Chrysomelidae), in the laboratory. J. Kans. Entomol. Soc. 62: 108-116.

SAS Institute. 1999-2001 SAS ${ }^{\circledR}$ on-line documentation, version 8.2. SAS Institute, Cary, NC.

Strnad, S. P., and M. K. Bergman. 1987a. Distribution and orientation of western corn rootworm (Coleoptera: Chrysomelidae) larvae in corn roots. Environ. Entomol. 16: 1193-1198.

Strnad, S. P., and M. K. Bergman. 1987b. Movement of firstinstar western corn rootworms (Coleoptera: Chrysomelidae) in soil. Environ. Entomol. 16: 975-978.

Strnad, S. P., M. K. Bergman, and W. C. Fulton. 1986. Firstinstar western corn rootworm (Coleoptera: Chrysomeldiae) response to carbon dioxide. Environ. Entomol. 15: $839-842$

Vaughn, T., T. Cavato, G. Brar, T. Coombe, T. DeGooyer, S. Ford, M. Groth, A. Howe, S. Johnson, K. Kolacz, et al. 2005. A method of controlling corn rootworm feeding 
using a Bacillus thuringiensis protein expressed in transgenic maize. Crop Sci. 45: 931-938.

Wright, R. J., M. E. Scharf, L. J. Meinke, X Zhou, B. D. Siegfried, and L. D. Chandler. 2000. Larval susceptibility of an insecticide-resistant western corn rootworm (Coleoptera: Chrysomelidae) population to soil insecticides: laboratory bioassays, assays of detoxification enzymes, and field performance. J. Econ. Entomol. 93: $7-13$.

Received 15 June 2005; accepted 22 February 2006. 